\title{
ENERGY EFFICIENCY OF TWO TYPES OF GREENHOUSES HEATED BY BIOMASS
}

\author{
VINDIS, P.; LAKOTA, M.; BERK, P. \& STAJNKO, D.
}

Abstract: The aim of my thesis was to discuss the heat losses occurring in plastic greenhouses comparing to glasshouses. Furthermore, we calculated the required amount of fuel and compare the results with the actual biomass consumption during two months period. Using temperature measurements and heat loss calculations we can conclude that there was no difference between two types of greenhouse since in gardening 1 heat loss per unit of volume was $1.12 \mathrm{~kW} / \mathrm{m}^{3}$ comparing to gardening 2 where heat loss per unit of volume reached $1.22 \mathrm{~kW} / \mathrm{m}^{3}$. Calculated fuel consumption per unit of volume was $6.78 \mathrm{~kg} / \mathrm{m}^{3}$ in gardening 1 and $7.36 \mathrm{~kg} / \mathrm{m}^{3}$ in gardening 2, which is also comparable to actual biomass consumption $\left(7.17 \mathrm{~kg} / \mathrm{m}^{3}\right.$ in gardening1 and $7.58 \mathrm{~kg} / \mathrm{m}^{3}$ in gardening 2). Considering higher degree days in the gardening 2 and other parameters we can conclude that glasshouses in gardening 2 are more energy efficient.

Key words: wood biomass, plastic greenhouse, glass greenhouse, heat loss, fuel consumption
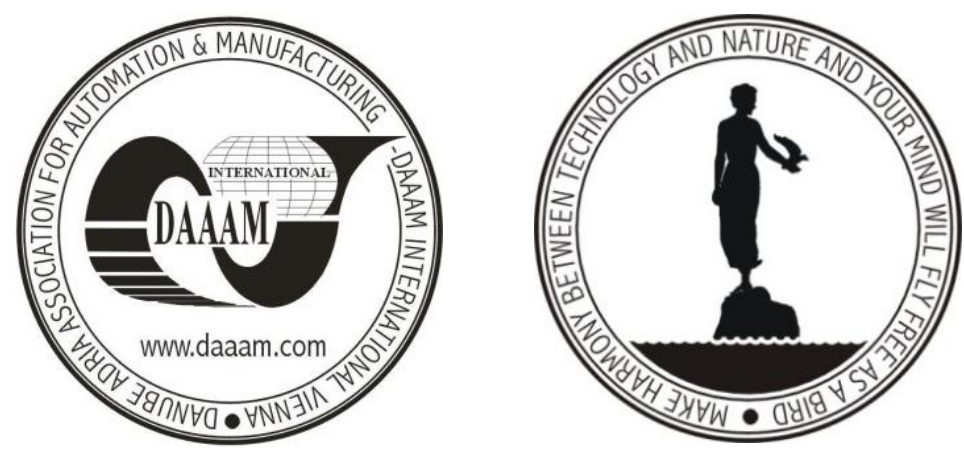

Authors' data: Assist. Prof. Dr. Vindis, P[eter]; Assoc. Prof. Stajnko, D[enis]; Bs. Elect. Eng. Berk, P[eter]; Assoc. Prof. Lakota, M[iran], University of Maribor, Faculty of Agriculture and Life Sciences, Pivola 10, SI-2311, Hoce, Slovenia, peter.vindis@uni-mb.si, miran.lakota@uni-mb.si

peter.berk@uni-mb.si,

This Publication has to be referred as: Vindis, P[eter]; Lakota, M[iran]; Berk, P[eter] \& Stajnko, D[enis] (2012). Energy Efficiency of Two Types of Greenhouses Heated by Biomass, Chapter 14 in DAAAM International Scientific Book 2012, pp. 157-168, B. Katalinic (Ed.), Published by DAAAM International, ISBN 978-3901509-86-5, ISSN 1726-9687, Vienna, Austria

DOI: $10.2507 /$ daaam.scibook.2012.14 
Vindis, P.; Lakota, M.; Berk, P. \& Stajnko, D.: Energy Efficiency of Two Type...

\section{Introduction}

Indoor heating represents a high cost in the process of growing of plants, so the choice of heating system is very important in reducing production costs. Heating with wood biomass represents one of the optimum heating systems, which due to exploitation of domestic wood products is gaining importance. It is important that with proper wood burning the air is not polluted (in the air only $\mathrm{CO}_{2}$ and $\mathrm{H}_{2} \mathrm{O}$ are released) and that the exploitation of wood residues influences better maintenance of forests. Sometimes the burning of wood belonged to the time consuming procedures, which is not acceptable for today's increasingly rapid rhythm of life. During the last decades in the wood heating the technology made a major step forward. However, despite advances in technology, room heating leads to heat losses (Krajnc \& Kopse, 2005).

Wood biomass is wood used for energy purposes. The efficient use of biomass for energy purposes means modern and efficient use of all forms of wood for heating and hot water. Wood biomass is used in very different forms from traditional logs to chips and other forms (briquettes and pellets). Wood used for energy purposes is a round timber of inferior quality, small wood, branch wood, wood scraps, sawdust, wood dust and uncontaminated waste wood (Kopse \& Krajnc, 2005).

Heat losses, calculated per unit of gross volume of the building are the sum of the transmission heat losses, where heat is transferred due to higher internal temperatures through walls, windows, ceiling to the outside and the heat losses due to ventilation. The latter leads to loss of heat needed for heating of air, which flows through the building. Transmission heat losses can be determined fairly accurately (with the known values of the external insulation of walls, windows, ceilings) on the basis of building drawings, determination of ventilation losses is approximately the sum of the losses incurred in this case due to natural ventilation and losses due to leakage of windows, doors and the effect of wind (Berk et al., 2010). The latter was neglected in our calculation to take into account only the losses caused by ventilation. The total heat required for heating of the building is made up of transmission heat and ventilation heat losses, while in the calculation any additional losses, such as the allowance for interruption of heating, allowance for cold surface temperature equalization, allowance for the position of sky etc were neglected (Stajnko et al., 2009).

\section{Methods}

In the experiment two gardens (garden 1 and garden 2) were compared in which wood chips are used for heating.

Garden 1 is located in Kamnica near Maribor. It has a $1693 \mathrm{~m}^{2}$ of covered area, where seven plastic greenhouses ornamental plants are produced. Its plastic greenhouses are of different manufacturers, basically are all made up of galvanized iron structure, aluminum sections and tubes, polycarbonate plates for the front side of greenhouse and UV polyethylene foil with which the roof and side walls are covered. 
The garden began to heat plastic greenhouses with wood chips in early 2009, which has already proved to be good investment. The amount of stored biomass is $150-200 \mathrm{~m}^{3}$ with predicted consumption of $10-20 \mathrm{~m}^{3}$ per month. For heating pine wood is used. Garden 1 has a heating device Fröling of Austrian manufacturer, whose main characteristics are given in Table 1 . Figure 1 shows heating device of garden 1 (Fröling Turbomat).

\begin{tabular}{|c|c|c|}
\hline $\begin{array}{c}\text { Type of heating } \\
\text { device }\end{array}$ & Heating device of garden 1 & Heating device of garden 2 \\
\hline $\begin{array}{c}\text { Year of } \\
\text { manufacture }\end{array}$ & 2009 & $\begin{array}{c}\text { D'alessandro termomeccanica } \\
\text { CSA }\end{array}$ \\
\hline $\begin{array}{c}\text { Rated power of } \\
\text { boiler }\end{array}$ & $220 \mathrm{~kW}$ & 2007 \\
\hline Max. pressure & $3 \mathrm{bar}$ & $3 \mathrm{kar}$ \\
\hline $\begin{array}{c}\text { Fuel thermal } \\
\text { output }\end{array}$ & $240 \mathrm{~kW}$ & $218 \mathrm{KW}$ \\
\hline $\begin{array}{c}\text { Max. working } \\
\text { temperature }\end{array}$ & $95^{\circ} \mathrm{C}$ & $90{ }^{\circ} \mathrm{C}$ \\
\hline $\begin{array}{c}\text { Max. } \\
\text { temperature }\end{array}$ & $110^{\circ} \mathrm{C}$ & $120{ }^{\circ} \mathrm{C}$ \\
\hline $\begin{array}{c}\text { Amount of } \\
\text { water }\end{array}$ & 5701 & 5001 \\
\hline
\end{tabular}

Tab. 1. Data of heating device of garden 1 and garden 2

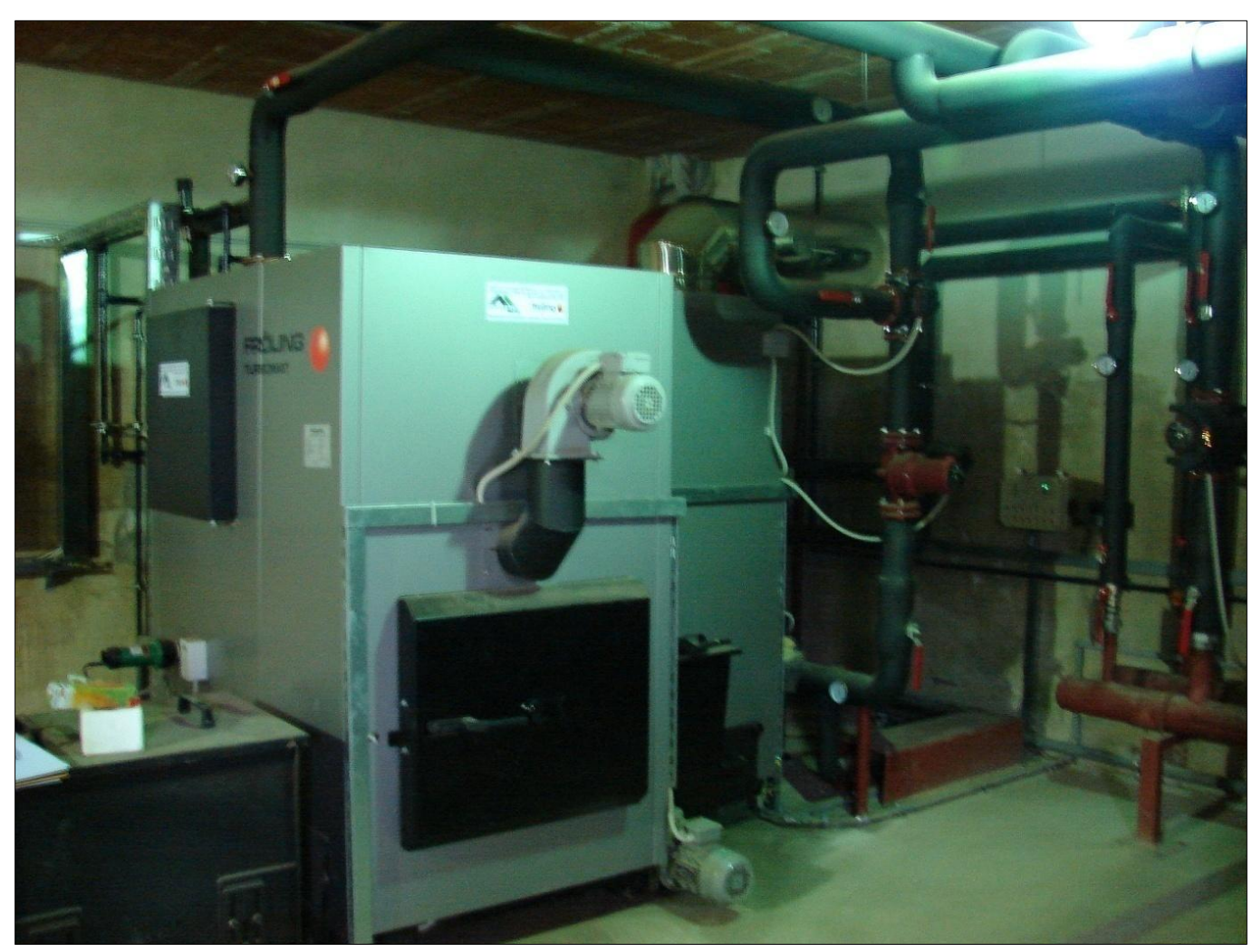

Fig. 1. Heating device Fröling Turbomat of garden 1 
Vindis, P.; Lakota, M.; Berk, P. \& Stajnko, D.: Energy Efficiency of Two Type...

Garden 2 is located in St. Jurij on Scavnici. Garden has today about $4200 \mathrm{~m}^{2}$ of area, of which approximately $1600 \mathrm{~m}^{2}$ are covered with plastic greenhouses. The garden is engaged in producing various kinds of ornamental plants, it offers also the landscaping of environment and graves. Its glass-greenhouses are of Dutch producer Venlo, consisting of galvanized iron structure, aluminum sections and tempered glass for roof and ordinary glass for walls. The garden began to heat glass greenhouses with wood chips in 2007, which has already proved as a good investment. It uses pine wood for heating of glass greenhouses. The amount of stored biomass is $70 \mathrm{~m}^{3}$ with the predicted consumption of $15 \mathrm{~m}^{3}$ per month. Garden 2 has the heating device D'Alessandro Termomeccanica of Italian manufacturer, whose main characteristics are given in Table 1. Figure 2 shows heating device of garden 2 (D'Alessandro Termomeccanica).

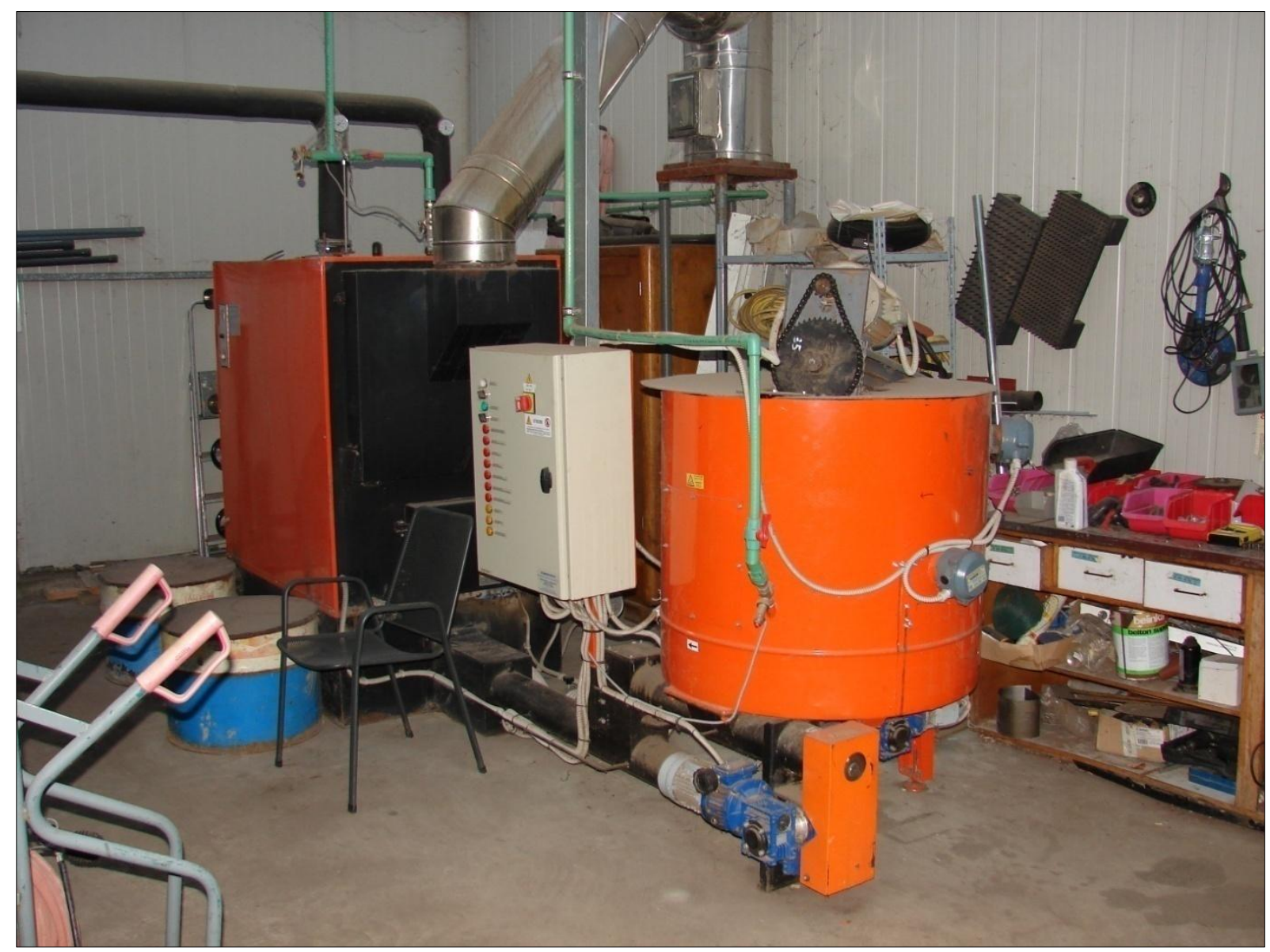

Fig. 2. Heating device D'Alessandro Termomeccanica of garden 2

\section{Equations for calculating heat losses according to standard SIST EN 832}

To calculate the heat losses the Rules on thermal insulation and energy efficiency in buildings (UL RS št.42/2002) and equations for calculating heat losses according to SIST EN 832 were applied.

The calculation of the coefficient of transmission heat losses (HT) due to the heat transfer through the building envelope: 


$$
\mathrm{H}_{\mathrm{T}}=\mathrm{L}_{\mathrm{D}}+\mathrm{L}_{\mathrm{S}} \quad[\mathrm{W} / \mathrm{K}]
$$

Where:

$\mathrm{L}_{\mathrm{D}}[\mathrm{W} / \mathrm{K}]$ - direct specific heat losses through the building envelope from the heated space into the exterior,

$\mathrm{L}_{\mathrm{S}}[\mathrm{W} / \mathrm{K}]$ - specific heat loss through the floor.

Calculation of the direct specific heat loss through the building envelope:

$$
\mathrm{L}_{\mathrm{D}}=\sum_{\mathrm{i}} \mathrm{A}_{\mathrm{i}} * \mathrm{U}_{\mathrm{i}} \quad[\mathrm{W} / \mathrm{K}]
$$

Where:

$A_{i}\left[\mathrm{~m}^{2}\right]$ - surface of the element $\mathrm{i}$ which is a part of the building envelope, $\mathrm{U}_{\mathrm{i}}\left[\mathrm{W} / \mathrm{m}^{2} \mathrm{~K}\right]-$ heat transfer of the element $\mathrm{i}$.

In case where $\mathrm{T} 1<\mathrm{T} 2$, the heat flux is negative, which means that heat is transferred from the exterior into the building.

Equivalent thermal conductivity is calculated by the equation:

$$
\mathrm{U}_{\mathrm{eq}}=\mathrm{U}-\mathrm{G}^{*} \mathrm{~S} \quad\left[\mathrm{~W} / \mathrm{m}^{2} \mathrm{~K}\right]
$$

Where:

$\mathrm{U}_{\text {eq }}\left[\mathrm{W} / \mathrm{m}^{2} \mathrm{~K}\right]$ - equivalent thermal conductivity of glazing and foil,

$\mathrm{U}\left[\mathrm{W} / \mathrm{m}^{2} \mathrm{~K}\right]$ - thermal conductivity of glazing, $\mathrm{G}$ - common transition of solar energy (solar factor),

$\mathrm{S}\left[\mathrm{W} / \mathrm{m}^{2} \mathrm{~K}\right]$ - coefficient of obtained solar energy depending on direction, in which an object is oriented (South: 2,4 W/m² $\mathrm{K}$; East/west: 1,65 W/m² $\mathrm{K}$; North: 0,95 W/m² $\mathrm{K}$ ).

The whole transmission of solar energy is given by the equation:

Where:

$$
\mathrm{g}=\mathrm{F}_{\mathrm{w}} * \mathrm{~g}_{\mathrm{T}}
$$

$\mathrm{g}_{\mathrm{T}}$ - transmission of solar energy for radiation, which is perpendicular to the glazing, $\mathrm{F}_{\mathrm{w}}-$ correction factor, $\mathrm{g}$ - total transmission of solar energy.

In case of plastic greenhouses and glass greenhouses for calculation of direct specific heat loss through the building envelope the adapted equation with considered heat load due to solar radiation is applied.

$$
\mathrm{L}_{\mathrm{D}}=\sum_{\mathrm{i}} \mathrm{A}_{\mathrm{i}} * \mathrm{U}_{\text {ieq }} \quad[\mathrm{W} / \mathrm{K}]
$$


Vindis, P.; Lakota, M.; Berk, P. \& Stajnko, D.: Energy Efficiency of Two Type...

Where:

$A_{i}\left[m^{2}\right]$ - surface of element $i$ which is a part of the building envelope, $\mathrm{U}_{\text {ieq }}\left[\mathrm{W} / \mathrm{m}^{2} \mathrm{~K}\right]$ - equivalent of thermal conductivity of element $\mathrm{i}$.

The calculation of transmission heat losses through the floor

In addition to heat loss through walls, transmission through the floor is a very important heat loss. It is calculated by the equation:

$$
\mathrm{L}_{\mathrm{S}}=\mathrm{A} * \mathrm{U} \quad[\mathrm{W} / \mathrm{K}]
$$

Where:

A $\left[\mathrm{m}^{2}\right]$ - floor area,

$\mathrm{U}\left[\mathrm{W} / \mathrm{m}^{2} \mathrm{~K}\right]-$ thermal conductivity of soil $\left(\mathrm{U}_{\text {concrete }(10 \mathrm{~cm})}=2 \mathrm{~W} / \mathrm{m}^{2} \mathrm{~K}, \mathrm{U}_{\text {soil }}=1,5\right.$ $\left.\mathrm{W} / \mathrm{m}^{2} \mathrm{~K}\right)$.

The calculation of heat losses due to natural ventilation

The procedure of calculating the coefficient of thermal losses due to ventilation $(\mathrm{HV})$ is given with equation:

$$
\mathrm{HV}=\mathrm{V}_{\mathrm{Z}} * \rho_{\mathrm{a}}^{*} \mathrm{c}_{\mathrm{a}}
$$

Where:

$\mathrm{V}_{\mathrm{Z}}\left[\mathrm{m}^{3} / \mathrm{h}\right]$ - rate of air flow through the building, taking into account the air flow through unheated rooms, $\rho_{\mathrm{a}}{ }^{*} \mathrm{c}_{\mathrm{a}}\left[\mathrm{J} / \mathrm{m}^{3} \mathrm{~K}\right]-$ the volume heat capacity of air $\left(\rho_{\mathrm{a}}{ }^{*} \mathrm{c}_{\mathrm{a}}=1200 \mathrm{~J} / \mathrm{m}^{3} \mathrm{~K}\right)$.

Airflow rate (VZ) can be calculated using the foreseen air exchange rate $\mathrm{n}$ which is in our case 0.1 air changes per hour:

$$
\mathrm{VZ}=\mathrm{n} * \mathrm{~V} * 24
$$

Where:

$\mathrm{V}\left[\mathrm{m}^{3}\right]$ - volume of heated room, calculated by taking into account the internal dimensions, $\mathrm{n}\left[\mathrm{h}^{-1}\right]$ - foreseen air exchange rate per hour.

24 - time factor.

Calculation of coefficient of total heat loss of building $\mathrm{H}$

Coefficient of total heat loss $(\mathrm{H})$ of heated space is the sum of the coefficient of transmission heat loss (HT) and coefficient of heat losses due to ventilation (HV). 


$$
\mathrm{H}=\mathrm{H}_{\mathrm{T}}+\mathrm{H}_{\mathrm{V}}
$$

$[\mathrm{W} / \mathrm{K}]$

Where:

$\mathrm{H}_{\mathrm{T}}[\mathrm{W} / \mathrm{K}]$ - transmission heat loss coefficient, $\mathrm{H}_{\mathrm{V}}[\mathrm{W} / \mathrm{K}]-$ coefficient of thermal losses due to ventilation.

\section{Calculation of temperature deficit}

Heat deficit is the sum of the differences of external air temperature and the selected temperature in the heated room and is calculated by the formula:

$$
\mathrm{DD}=\mathrm{N}^{*}{ }_{\mathrm{Ti}, \mathrm{p}}-\mathrm{T}_{(\mathrm{e}, \text { season })} \quad[\mathrm{K}]
$$

Where:

$\mathrm{N}$ - number of days in the heating season,

$\mathrm{T}_{\mathrm{i}, \mathrm{p}}$ - design temperature of heated rooms in the building,

$\mathrm{T}_{\mathrm{e} \text {, season }}$ - the average temperature in the heating season.

For this study the outdoor temperatures for two months were monitored, so the formula for calculating the temperature deficit was adjusted slightly. Temperature deficit was calculated for each day and for each plastic and glass greenhouse separately.

$$
\mathrm{DD}=\sum_{\mathrm{i}}\left(\mathrm{T}_{\mathrm{i}, \mathrm{p}}-\mathrm{T}_{\mathrm{e}, \mathrm{o}}\right) \quad[\mathrm{K}]
$$

Where:

$\mathrm{T}_{\mathrm{e}, \mathrm{o}}$ - average daily temperature,

$\mathrm{i}$ - days of measurement.

Calculation of total heat loss of the building (QI)

Total heat loss of the building depends on the coefficient of total heat loss of the building and temperature deficit and is calculated by the equation:

$$
\mathrm{QI}=\mathrm{H}^{*} \mathrm{DD} \quad[\mathrm{kWh}]
$$

Where:

$\mathrm{H} \quad[\mathrm{W} / \mathrm{K}]-$ coefficient of total heat loss of the building,

DD $[\mathrm{K}]$ - temperature deficit.

The sum of all heat losses of plastic greenhouses and glass greenhouses

Heat losses of all plastic and glass greenhouses of the garden are the sum of heat loss of individual plastic and glass greenhouses. They are calculated by the equation: 
Vindis, P.; Lakota, M.; Berk, P. \& Stajnko, D.: Energy Efficiency of Two Type...

$$
\mathrm{Q}=\sum \mathrm{Q}_{\mathrm{I}} \quad[\mathrm{kWh}]
$$

Where:

Q $\quad[\mathrm{kWh}]-$ total heat loss of the building.

Calculation of fuel consumption for heating

It is calculated by the equation:

$$
\mathrm{m}_{\mathrm{g}}=\mathrm{Q}^{*}\left(3,6^{*} \tau\right) /\left(\mathrm{H}_{\mathrm{i}}^{*} \eta\right) \quad[\mathrm{kg}]
$$

Where:

3,6 - conversion factor,

$\tau[\mathrm{h} /$ day $]$ - number of burning hours in the day (usually $24 \mathrm{~h} /$ day),

$\mathrm{H}_{\mathrm{i}}[\mathrm{kJ} / \mathrm{kg}]$ - lower heating value,

$\eta$-efficiency of heating device.

Calculation of total heat loss per unit volume of individual greenhouses

Total heat loss per unit volume of individual greenhouses is calculated by the equation:

$$
\mathrm{EK}=\mathrm{Q}_{\mathrm{I}} / \mathrm{V} \quad\left[\mathrm{kW} / \mathrm{m}^{3}\right]
$$

Where:

Q $[\mathrm{kWh}]$ - total heat loss of the building,

$\mathrm{V}\left[\mathrm{m}^{3}\right]$ - volume of greenhouse.

Fuel consumption per unit volume is calculated by the equation:

$$
\mathrm{M}_{\mathrm{g}}=\mathrm{m}_{\mathrm{g}} / \mathrm{V} \quad\left[\mathrm{kg} / \mathrm{m}^{3}\right]
$$

Where:

$\mathrm{m}_{\mathrm{g}}[\mathrm{kg}]$ - consumed fuel for heating,

$\mathrm{V}\left[\mathrm{m}^{3}\right]$ - volume of greenhouse.

\section{Results with discussion}

4.1 The calculation of heat losses of individual plastic greenhouses of garden 1

Due to large amounts of data, we present the results of garden 1 and comparison of the energy efficiency of both types of greenhouses. Table 2 shows the calculation of heat losses of the garden 1 . 


\begin{tabular}{|c|c|c|c|c|c|c|}
\hline Type of greenhouse & $\begin{array}{c}\mathbf{L}_{\mathbf{D}} \\
{[\mathbf{W} / \mathbf{K}]}\end{array}$ & $\begin{array}{c}\mathbf{L}_{\mathbf{S}} \\
{[\mathbf{W} / \mathbf{K}]}\end{array}$ & $\begin{array}{c}\mathbf{H}_{\mathbf{T}} \\
{[\mathbf{W} / \mathbf{K}]}\end{array}$ & $\begin{array}{c}\mathbf{H}_{\mathbf{V}} \\
{[\mathbf{W} / \mathbf{K}]}\end{array}$ & $\begin{array}{c}\mathbf{H} \\
{[\mathbf{W} / \mathbf{K}]}\end{array}$ & $\begin{array}{l}\sum_{\left[\mathbf{m}^{2}\right]} \mathbf{A} \\
\end{array}$ \\
\hline Plastic greenhouse 1 & I & I & I & 1 & l & \\
\hline Plastic greenhouse 2 & 2881,02 & 315,00 & 3196,02 & 29,77 & 3225,79 & \\
\hline Plastic greenhouse 3 & 2524,09 & 283.50 & 2807,59 & 25,20 & 2832,79 & \\
\hline Plastic greenhouse 4 & 2524,09 & 283.50 & 2807,59 & 25,20 & 2832,79 & \\
\hline $\begin{array}{l}\text { Plastic greenhouse } 5 \\
\end{array}$ & $\bar{T}$ & $\bar{T}$ & $\bar{T}$ & 7 & $\bar{T}$ & \\
\hline Plastic greenhouse 6 & I & I & I & I & I & \\
\hline Plastic greenhouse 7 & 1248,64 & 150,00 & 1398,64 & 14,17 & 1412,81 & \\
\hline Plastic greenhouse 1-7 & & & & & & 688 \\
\hline
\end{tabular}

Tab. 2. Heat losses of plastic greenhouses of garden 1

Table 2 shows that the highest total coefficient of heat losses was in garden 1 in plastic greenhouse 2 because it has the largest area and amounted to 3225,79 W/K. The total heated area of plastic greenhouses was $688 \mathrm{~m}^{2}$.

\subsection{Calculation of total heat losses of garden 1}

Table 3 shows the total heat losses of garden 1 in November and December 2009.

\begin{tabular}{|c|c|}
\hline Type of greenhouse & $\mathbf{Q}_{\mathbf{I}}[\mathbf{k W}]$ \\
\hline Plastic greenhouse 2 & 364,84 \\
\hline Plastic greenhouse 3 & 1237,36 \\
\hline Plastic greenhouse 4 & 891,76 \\
\hline Plastic greenhouse 7 & 703,30 \\
\hline$Q=\sum Q_{I}$ & 3197,26 \\
\hline
\end{tabular}

Tab. 3. Total heat losses of garden 1

Total heat loss in garden 1 was $3197,26 \mathrm{~kW}$. As seen in Table 3, the highest heat loss was in plastic greenhouse 3. Plastic greenhouse 3 has also the largest area and the largest temperature deficit.

\subsection{Calculation of fuel consumption for heating}

From the calculated total heat loss, the amount of fuel used for heating, in our case, the wood chips was calculated. The efficiency of heating system is according to the manufacturer at least $90 \%$. Lower heating value of wood chips is based on data from the literature and is between 14700 and $16700 \mathrm{~kJ} / \mathrm{kg}$ (Medved, 1997; Senegačnik, 2005). In calculating the amount of consumed fuel the value of 16,000 
Vindis, P.; Lakota, M.; Berk, P. \& Stajnko, D.: Energy Efficiency of Two Type...

$\mathrm{kJ} / \mathrm{kg}$ was used. The density of wood chips which amounts to $700 \mathrm{~kg} / \mathrm{m}^{3}$ (Kopše and Krajnc, 2005) from the volume $\left(\mathrm{m}^{3}\right)$ of consumed biomass was calculated.

Table 4 shows consumption of wood biomass in garden 1.

\begin{tabular}{|c|c|}
\hline $\begin{array}{c}\text { Consumption of wood } \\
\text { biomass [kg] }\end{array}$ & $\begin{array}{c}\text { Consumption of wood } \\
\text { biomass }\left[\mathbf{m}^{\mathbf{3}}\right]\end{array}$ \\
\hline $19.183,56$ & 27,40 \\
\hline
\end{tabular}

Tab. 4. Consumption of wood biomass in garden 1

4.4 Calculation of total heat loss per unit volume in the plastic greenhouses of garden 1

Table 5 shows the calculation of total heat loss per unit volume in the plastic greenhouses of garden 1 for a period of two months.

\begin{tabular}{|c|c|c|c|}
\hline Type of greenhouse & $\begin{array}{c}\text { Volume } \\
{\left[\mathbf{m}^{\mathbf{3}}\right]}\end{array}$ & $\begin{array}{c}\text { Total heat } \\
\text { loss } \\
{[\mathbf{k W}]}\end{array}$ & $\begin{array}{c}\text { Total heat loss } \\
\text { per unit volume } \\
{\left[\mathbf{k W} / \mathbf{m}^{\mathbf{3}}\right]}\end{array}$ \\
\hline Plastic greenhouse 2 & 893 & 364,84 & 0,41 \\
\hline Plastic greenhouse 3 & 756 & 1237,36 & 1,64 \\
\hline Plastic greenhouse 4 & 756 & 891,76 & 1,18 \\
\hline Plastic greenhouse 7 & 425 & 703,30 & 1,65 \\
\hline
\end{tabular}

Tab. 5. Total heat loss per unit volume of individual plastic greenhouses of garden 1

Table 5 shows that the maximum heat losses per unit volume were in the plastic greenhouses 3 and 7, because there was the greatest temperature deficit. Minimum heat loss per unit volume was in plastic greenhouse 2 .

\subsection{Calculation of fuel consumption per unit volume in the garden 1}

Table 6 shows, that the calculated fuel consumption per unit volume which amounted to $6,78 \mathrm{~kg} / \mathrm{m}^{3}$, is less than actually consumed, which was $7,17 \mathrm{~kg} / \mathrm{m}^{3}$. Actual fuel consumption during the measurements was $29 \mathrm{~m}^{3}$.

\begin{tabular}{|c|c|c|c|c|c|}
\hline $\begin{array}{c}\text { Type of } \\
\text { greenhouse }\end{array}$ & Total \\
volume & $\begin{array}{c}\text { The } \\
\text { calculated } \\
\text { fuel } \\
{\left[\mathbf{m}^{\mathbf{3}}\right]}\end{array}$ & $\begin{array}{c}\text { Fuel } \\
\text { consumption } \\
{[\mathbf{k g}]}\end{array}$ & $\begin{array}{c}\text { The calculated } \\
\text { consumption } \\
\text { fkg] }\end{array}$ & $\begin{array}{c}\text { Fuel } \\
\text { consumption } \\
\text { /unit volume } \\
{\left[\mathbf{k g} / \mathbf{m}^{\mathbf{3}}\right]}\end{array}$ & $\begin{array}{l}\text { / unit volume } \\
{\left[\mathbf{k g} / \mathbf{m}^{\mathbf{3}}\right]}\end{array}$ \\
\hline $\begin{array}{c}\text { Plastic } \\
\text { greenhouse }\end{array}$ & 2830,00 & $19.183,56$ & $20.300,00$ & 6,78 & 7,17 \\
\hline
\end{tabular}

Tab. 6. Fuel consumption per unit volume 
4.6 Comparison of the energy efficiency of both types of greenhouses

Table 7 and 8 show the comparison of calculated and actual parameters calculated using the equations presented.

\begin{tabular}{|c|c|c|c|}
\hline $\begin{array}{c}\text { Type of } \\
\text { greenhouse }\end{array}$ & $\begin{array}{c}\mathrm{V} \\
{\left[\mathrm{m}^{3}\right]}\end{array}$ & $\begin{array}{c}\mathrm{Q} \\
{[\mathrm{kW}]}\end{array}$ & $\begin{array}{c}\mathrm{E}_{\mathrm{K}} \\
{\left[\mathrm{kW} / \mathrm{m}^{3}\right]}\end{array}$ \\
\hline Garden 1 & 2830 & $3.197,26$ & 1,12 \\
\hline Garden 2 & 6555 & $8.045,60$ & 1,22 \\
\hline
\end{tabular}

Tab. 7. Comparison of total heat loss per unit volume in both gardens

Table 7 shows that the heat loss per unit volume is higher in the garden 2, i.e. in the glass greenhouses. Higher heat losses were expected in the plastic greenhouses, due to increased heat transfer of materials from which they are made, but they are larger in the glass greenhouses due to lower average external temperature during November and December.

\begin{tabular}{|c|c|c|c|c|c|c|}
\hline $\begin{array}{c}\text { Type of } \\
\text { greenhou } \\
\text { se }\end{array}$ & $\begin{array}{c}\mathbf{m}_{\mathbf{g}} \\
{[\mathbf{k g}]}\end{array}$ & $\begin{array}{c}\mathbf{m}_{\mathbf{p}} \\
{[\mathbf{k g}]}\end{array}$ & $\begin{array}{c}\mathbf{M}_{\mathbf{g}} \\
{\left[\mathbf{k g} / \mathbf{m}^{3}\right]}\end{array}$ & $\begin{array}{c}\mathbf{M}_{\mathbf{p}} \\
{\left[\mathbf{k g} / \mathbf{m}^{3}\right]}\end{array}$ & $\begin{array}{c}\text { The } \\
\text { calculated } \\
\text { fuel } \\
\text { consumption } \\
{\left[\mathbf{m}^{\mathbf{3}}\right]}\end{array}$ & $\begin{array}{c}\text { Fuel } \\
\text { consumption } \\
{\left[\mathbf{m}^{\mathbf{3}}\right]}\end{array}$ \\
\hline Garden 1 & $19.183,56$ & $20.300,00$ & 6,78 & 7,17 & 27,40 & 29,00 \\
\hline Garden 2 & $48.273,58$ & $49.700,00$ & 7,36 & 7,58 & 68,97 & 71,00 \\
\hline
\end{tabular}

Tab. 8. Comparison of consumed wood biomass in kilograms and cubic meters in both gardens

Table 8 shows that the calculated fuel consumption in both kilograms and cubic meters is less than the actual consumption, as was expected. Is heat loss certain parameters such as allowances for interruption of heating, equalizing the temperature of cold surfaces, the side of the sky, losses arising from leaks of doors and windows and the impact of the wind were ignored.

\section{Conclusion}

The aim of this study was to determine the energy efficiency of both types of greenhouses. Based on the measurements, estimates and calculations, some interesting conclusions were reached.

Total heat loss per unit volume was greater in garden 2, i.e. in the glass greenhouses. The heat loss depends on the coefficients of heat transfer and temperature deficit, so we expected greater heat losses in the plastic greenhouses. Lower outside temperatures (especially in December) and the higher required 
temperatures in the glass greenhouses (greater temperature deficit) were a key influence on the higher heat loss in the glass greenhouses. Consequently, the fuel consumption is greater in the glass greenhouses, since it also depends on the total heat loss. The calculated fuel consumption is smaller than actual consumption expected in both types of greenhouses. The cause are the additional heat losses that occur unexpectedly (due to excessive door opening) and in our calculations are not considered. Taking into account all the parameters we can conclude that the glass greenhouses are more energy-efficient, but people still tend to opt for installing plastic greenhouses, as these are particularly affordable.

Future research will focus on reducing heat losses in plastic greenhouses, finding new materials for greenhouses, improving efficiency of heating devices and finding a better quality chips for heating and so reduce the costs of production.

\section{References}

Kopse, I. \& Krajnc, N. (2005). Heating with wood, Forest Service of Slovenia, Ljubljana

Krajnc, N. \& Kopse, I. (2005). Wood - renewable and environmentally friendly energy source, Forest Service of Slovenia, Ljubljana

Official Journal RS, No. 42/2002, day 15. 5. 2002

Medved, S. (1997). Thermal technology in buildings, University of Ljubljana, Ljubljana

Senegačnik, A. (2005). Wood biomass, Forum Economy exhibition, Ljubljana

Stajnko, D.; Vindis, P. \& Mursec, B. (2009). Reduction of $\mathrm{CO}_{2}$ emission in production of corn in Slovenia. DAAAM International Scientific Book, Vienna, Daaam international publishing, 573-586

Berk, P., Vindis, P., Lakota, M., Ocepek, M \& Rakun, J. (2011). Artificial neural network for identification of large letters of the alphabet. DAAAM International Scientific Book, Vienna: Daaam international publishing, 401408 